Sitasi artikel ini (APA $6^{\text {th }}$ Edition style):

Puspitosari, R. (2018). Sekilas tentang Pendidikan di Praja Mangkunegaran Masa Mangkunegoro VII, 1917-1944. MUKADIMAH, 1(2), 172-178.

\title{
Sekilas tentang Pendidikan di Praja Mangkunegaran Masa Mangkunegoro VII, 1917-1944
}

\author{
Retno Puspitosari \\ Dinas Kearsipan dan Perpustakaan Provinsi Jawa Tengah \\ puspitosarisayuto@gmail.com
}

\begin{abstract}
ABSTRAK
Salah satu dampak pentingnya dari dilaksanakannya program studiefonds adalah telah munculnya golongan terpelajar baru sebagai elite modern yang berusaha mengubah tatanan masyarakat yang selama ini tertindas oleh kepentingan penjajah. Berkaitan dengan itu segera mereka memunculkan gerakan-gerakan baik politik, kultural maupun kemasyarakatan. Hal ini merupakan bentuk awal kesadaran nasional terutama pada awal abad XX, berupa kesadaran untuk melepaskan diri dari cengkeraman kolonialisme melalui golongan terpelajar yang sebagian di antaranya dibiayai dari dana studiefonds. Studiefonds berjalan lancar dan peminatnya semakin banyak, karena usaha tersebut memang benar-benar merupakan suatu fenomena baru bagi dunia pengajaran di Praja Mangkunegaran yang sangat menguntungkan bagi mereka yang berprestasi tetapi tidak mempunyai biaya untuk sekolah.
\end{abstract}

Kata kunci: Pendidikan, Praja Mangkunegaran, Mangkunegoro VII.

\section{PENDAHULUAN}

Pendidikan di Jawa khususnya dan di Indonesia pada umumnya, telah mendorong timbulnya pergerakan nasional. Pendidikan formal di Indonesia mengalami kemajuan cukup pesat terutama setelah penerapan "Politik Etis", yang dipelopori oleh Van Deventer dan dikenal dengan Trilogi Van Deventer yang menekankan supaya masyarakat Kolonial di Hindia Belanda diberi hak untuk memperbaiki hidupnya.

Pada akhir abad ke-19 terjadi perubahan dalam peta politik pemerintahan Belanda di Indonesia, dari politik kolonial liberal yang telah dijalankan sejak tahun 1870 dengan suatu tatanan politik baru yang lebih menekankan pada kesejahteraan rakyat Indonesia. Garis politik baru tersebut dikenal sebagai "Politik Etis", yang diperkenalkan pertama kali secara resmi dalam pidato tahunan Kerajaan Belanda pada bulan September 1901 (Niel, 1984, p. 51). Kebijaksanaan baru ini dimulai terutama karena pengaruh beberapa orang Belanda yang menunjukkan adanya "eereschuld" (hutang kehormatan) negeri Belanda terhadap jajahannya, yaitu Indonesia yang telah 
sekian lama memberikan keuntungan kepada mereka. Berapa cara untuk mengeruk keuntungan adalah antara lain dengan Sistem Tanam Paksa (cultuurstelsel), yang telah membuat rakyat Indonesia menderita (Poeponegoro \& Notosusanto, 1984, p. 14).

Politik Etis paling tampak dalam bidang pendidikan dan pengajaran, karena jumlah guru, sekolah dan murid meningkat dengan pesat. Fasilitas pendidikan untuk orang Indonesia di Jawa bertambah pesat dan dari perluasan dan perkembangan pendidikan inilah ditemukan akar perubahan sosial yang mempengaruhi elite Indonesia. Pada mulanya orang Jawa yang ingin berpendidikan Barat, tidak mendapat dukungan bahkan kadang-kadang mengalami tantangan dari pihak orang tua. Mereka takut akan pengaruhnya bagi kedudukan sosial anak-anak mereka selanjutnya, karena pemerintah kolonial Belanda tetap membatasi perkembangan masalah ini.

Perjuangan untuk melancarkan politik kolonial yang progresif itu diteruskan oleh tokoh-tokohnya antara lain: Van Kol, Van Deventer dan Brooschooft. Mereka menginginkan mengubah pandangan dalam politik kolonial yang beranggapan bahwa Indonesia tidak lagi sebagai suatu daerah yang hanya selalu menguntungkan Belanda, tetapi juga menjadi suatu daerah yang perlu dikembangkan dan ditingkatkan kesejahteraannya.

Pandangan tersebut telah terkandung dalam slogan Politik Etis yaitu "Irigasi, Edukasi dan Emigrasi" (Kartodirdjo, 1972, p. 21). Beberapa slogan tersebut ternyata bukan hanya sebuah tulisan di atas kertas saja, tetapi ternyata pemerintah Hindia Belanda ingin mewujudkannya. Untuk itu secara bertahap pemerintah Hindia Belanda segera mewujudkan slogan Politik Etis tersebut.

Dalam bidang pendidikan (edukasi), pemerintah Belanda mulai memperluas kesempatan bagi rakyat Indonesia khususnya dari kalangan atas, untuk mengikuti pendidikan di sekolah-sekolah yang berbahasa Belanda. Selama itu sekolah-sekolah berbahasa Belanda hanya menerima siswa yang berasal dari rakyat Indonesia sampai pada tingkat dasar dan menengah, belum sampai tingkat atas. Kondisi tersebut sudah merupakan sebuah kemajuan, sebab sebelum adanya Poltik Etis hal itu sangatlah tidak mungkin terjadi. Sejak saat itu terjadi perluasan dan perkembangan pendidikan bagi rakyat Indonesia. Pada akhirnya hal itu berakibat timbulnya beragam elite di Indonesia (Niel, 1984, pp. 74-75). Salah satu program edukasi yang menghasilkan golongan elite baru di Indonesia adalah sekolah "Dokter Jawa" yang mengadakan reorganisasi pada tahun 1900-1902 dan kemudian berubah menjadi School Tot Opleiding Voor Inlandsche Artsen (STOVIA) dengan cara barat.

Program edukasi dalam Politik Etis mengakibatkan banyak kaum terpelajar ingin mengadakan perubahan sistem negaranya. Akibat lebih lanjut adalah munculnya pergerakan politik. Kemudian dari STOVIA itu muncul organisasi Indonesia yang pertama yang disusun dalam bentuk modern, Budi Utomo (Nagazumi, 1989, p. 14). 


\section{METODE DAN FOKUS PENELITIAN}

Metode yang digunakan adalah metode sejarah. Pada tahap heuristik data-data yang dikumpulkan berupa hasil dari penelitian kepustakaan dan telaah arsip. Kemudian dilanjutkan pada tahap verifikasi dengan melakukan kritik sumber. Sumber-sumber yang digunakan selanjutnya diinterpretasikan menjadi sebuah penafsiran sejarah yang didukung oleh fakta dan data yang kredibel. Pada tahap terakhir data sejarah tersebut disintesiskan dan ditulis dalam bentuk historiografi dalam konteks ini berupa artikel tentang deskripsi sejarah yang eksplanatif. Penelitian difokuskan pada lingkup keilmuan dalam hal pendidikan untuk kalangan pribumi, pada lingkup spasial mencakup wilayah Mangkunegaran dan pada lingkup temporal mencakup periode 1917-1944.

\section{HASIL DAN PEMBAHASAN}

Pemrakarsa berdirinya Budi Utomo adalah Dr. Wahidin Soedirohoesodo dan sebagai pendirinya antara lain adalah Dr. Soetomo. Organisasi ini berdiri di Jakarta pada tanggal 20 Mei 1908. Sebelum Budi Utomo lahir, Dr. Wahidin Soedirohoesodo telah berusaha untuk mendirikan studiefonds, sebagai upaya untuk memperluas pengajaran. Pada saat itu pendidikan dan pengajaran di Indonesia sangatlah menyedihkan dan mengecewakan. Hal itu disebabkan oleh kurangnya kesempatan bagi rakyat pribumi untuk menikmati pendidikan dan tidak sedikit pula faktor kekurangan biaya. Hal itu menjadi pendorong bagi para pelajar STOVIA untuk lebih memperluas usaha Dr. Wahidin Soedirohoesodo tersebut, yang pada akhirnya menjadi program utama organisasi Budi Utomo yaitu mengusahakan perbaikan pendidikan dan pengajaran (Tirtoprodjo, 1986, p. 11).

Memperluas dan memperbaiki pengajaran menjadi program utama Budi Utomo yang dilaksanakan hampir di semua daerah di Jawa dan Madura, khususnya yang ada cabangnya. Perluasan itu semakin pesat setelah diadakan Kongres Budi Utomo yang pertama di Yogyakarta pada tanggal 5 Oktober 1908 (A.K. Pringgodigdo, 1980, p. 1). Dalam rapat tersebut selain telah memantapkan tujuan perkumpulan seperti yang telah direncanakan di Jakarta pada tanggal 20 Mei 1908, terbentuklah pengurus besar. Terpilih sebagai ketua pada kongres tersebut adalah Raden Tumenggung Tirtokusumo, bupati Karanganyar. Dengan demikian, pimpinan telah beralih dari generasi muda kepada generasi yang lebih tua, terutama dari kalangan priyayi. Budi Utomo memang mempunyai arah kecenderungan untuk mempertahankan budaya Jawa dalam awal proses pembentukannya, sehingga dominasi lebih banyak pada kaum priyayi daripada rakyat biasa (Scherer, 1985, p. 55).

Dominasi priyayi dalam Budi Utomo sangatlah beralasan, karena sebenarnya golongan inilah yang mengenyam pendidikan dan dari golongan ini pula timbul kaum pergerakan nasional. Akibat peran serta priyayi ini terasa pula di Praja Mangkunegaran. Mangkunegoro VI sebagai pemegang tampuk pemerintahan pada masa itu, memprakarsai program-program Budi Utomo di Mangkunegaran. 
Salah satu wujud program Budi Utomo tersebut adalah pendirian sekolah "Siswo" khususnya diperuntukkan bagi kerabat dan abdi dalem Mangkunegaran, tetapi juga tidak menutup kemungkinan bagi masyarakat umum yang berminat. Selain mendirikan sekolah, Mangkunegoro VI juga memikirkan nasib para sentono dalem, abdi dalem dan hambanya yang tidak mampu membiayai anaknya untuk melanjutkan sekolah. Sebagai tindak lanjut dari pemikiran tersebut, didirikanlah studiefonds, yaitu suatu badan yang memberikan pinjaman uang untuk melanjutkan sekolah bagi anak-anak dari para sentono, abdi dalem dan hamba Mangkunegaran yang tidak mampu tetapi berprestasi. Ide Mangkunegoro VI tersebut mendapatkan dukungan dari Residen Surakarta pada waktu itu, G.F. van Wijk. Badan ini secara resmi berdiri dan mulai memberikan pinjaman dana belajar pada tahun 1912. Dasar yang mengatur jalannya pemberian pinjaman dana belajar tersebut telah diundangkan dalam Pranatan Pustaka Praja (Rijksblaad) No. 20 tahun 1917 dan dalam pelaksanaannya, Mangkunegoro VI dibantu oleh suatu Panitia Penasehat (Commissie van Advies).

Studiefonds berjalan lancar dan peminatnya semakin banyak, karena usaha tersebut memang benar-benar merupakan suatu fenomena baru bagi dunia pengajaran di Praja Mangkunegaran yang sangat menguntungkan bagi mereka yang berprestasi tetapi tidak mempunyai biaya untuk sekolah. Kesempatan emas ini tidaklah mereka sia-siakan begitu saja demi kemajuan bangsanya agar tidak lagi tertindas oleh bangsa lain.

Akhirnya setelah Mangkunegoro VI turun tahta pada tahun 1916 dan digantikan oleh Mangkunegoro VII, studiefonds tidak berhenti dan justru tetap mengalami perkembangan yang cukup pesat, karena Mangkunegoro VII sangat mendukung pendahulunya tersebut. Hal ini ditunjang pula dengan keadaan ekonomi Praja Mangkunegaran yang semakin membaik jika dibandingkan dengan keadaan ekonomi pada masa sebelumnya. Pada masa itu Mangkunegoro VII telah membakukan peraturan-peraturan yang berkaitan dengan pelaksanaan studiefonds. Commissie van Advies, yang khusus menangani studiefonds pun dibentuk olehnya. Mangkunegoro VII juga telah menambahkan satu sumber pendanaan baru untuk studiefonds yang berasal dari uang pribadinya, kemudian dikenal dengan nama Studiefonds Kas Daleman. Studiefonds sebagai sebuah usaha untuk memberikan bantuan kepada masyarakat yang kurang mampu ternyata telah melahirkan golongan terpelajar baru yang akan menjadi agen perubahan. Golongan terpelajar baru ini dikenal dengan "elite modern" yang bercirikan:

1) Bergaya hidup Barat seperti tampak di kota-kota besar.

2) Alam pikiran mereka tidak lagi terbatas pada alam pikiran tradisional.

3) Cita-cita mereka mengarah ke suatu satuan politik baru yang terlepas dari ikatan-ikatan tradisional maupun kolonial. 
4) Merupakan kelompok yang ikut ambil bagian dalam mekanisme birokrasi Barat, misalnya sebagai bupati, ambtenaar dan bagi golongan minoritas Tionghoa yaitu dengan mencoba ikut ambil bagian dalam Volksraad.

Salah satu dampak pentingnya dari dilaksanakannya program studiefonds adalah telah munculnya golongan terpelajar baru sebagai elite modern yang berusaha mengubah tatanan masyarakat yang selama ini tertindas oleh kepentingan penjajah. Berkaitan dengan itu segera mereka memunculkan gerakan-gerakan baik politik, kultural maupun kemasyarakatan. Hal ini merupakan bentuk awal kesadaran nasional terutama pada awal abad ke-20, berupa kesadaran untuk melepaskan diri dari cengkeraman kolonialisme melalui golongan terpelajar yang sebagian di antaranya dibiayai dari dana studiefonds.

Studiefonds, tidak hanya diberikan kepada anak laki-laki saja tetapi juga anak-anak perempuan. Menurut pemikiran Mangkunegoro VII bahwa sudah saatnya antara laki-laki dan wanita diberkan hak yang sama terutama dalam hal pendidikan. Menurut Mangkunegoro VII, ia tidak menginginkan wanita hanya sebagai selir dan terbelakang dalam hal pendidikannya. Mangkunegoro VII juga tidak menghendaki para generasi muda khususnya wanita kehilangan akar budayanya sebagai bangsa Jawa. Pemberian studiefonds adalah salah satu jalan untuk kaum wanita memperoleh haknya. Pada masa Mangkunegoro VII pula kaum wanita memperoleh kesempatan belajar seluas-luasnya. Hal ini ditandai dengan berdirinya sekolah Siswo Rini dan Sekolah Van Deventer (Solosche Van Deventer-School). Siswo Rini merupakan hasil pengembangan Sekolah Kelas II (Tweede Klasse School) yang didirikan bersamaan dengan HIS Siswo (Hollandsch Inlandsche School) pada tahun 1912 dan secara resmi berubah pada Juli 1924 menjadi kursus kerumahtanggaan istana.

\section{PENUTUP}

Pada tahun 1927 berdiri Sekolah Van Deventer yang mendapat dukungan secara penuh dari masalah perijinan sampai dengan biayanya. Mangkunegoro VII dan Permaisurinya menunjukan perhatian pada sekolah yang menggunakan kurikulum Belanda dan Jawa ini dengan menghadiri acara-acara maupun rapat yang diselenggarakan. Kurikulum tersebut sesuai dengan keinginan Mangkunegoro VII yaitu menyeimbangkan antara pengetahuan Barat dengan pengetahuan tradisional. Oleh karena itu Mangkunegoro VII memberikan beberapa keistimewaan bagi siswa-siswa sekolah tersebut untuk turut menggunakan fasilitas di istana. Sekolah Van Deventer menerima siswa putri dari berbagai kalangan, priyayi maupun masyarakat umum.

Wanita dapat melanjutkan ke tingkat lanjutan tentu saja sangat berhubungan erat dengan situasi zaman pada masa itu. Isu tentang pendidikan yang menjadi jiwa zaman disikapi oleh Mangkunegoro VII dengan pemerataan pendidikan yang sekaligus menjadi alat modernisasi budaya termasuk salah satunya adalah gaya hidup. Wanita-wanita yang menjadi alumni dari sekolah 
wanita pada masa Mangkunegoro VII tidak terlibat secara langsung dalam pergerakan nasional. Namun demikian mereka mulai bisa mengikuti perkembangan politik pada saat itu, antara lain dengan terlibat dalam organisasi budaya seperti Java Insituut dan mendirikan Perkumpulan Kaum Ibu Setiyowanito. Meskipun organisasi ini bertujuan membicarakan masalahmasalah dalam rumah tangga, para wantia tersebut mulai bisa mengeluarkan pendapat dan memahami tentang hak berkumpul seperti pada organisasi pergerakan nasional, hal ini merupakan pencapaian yang cukup besar jika dilihat pada lingkungan mana pendidikan ini berkembang.

\section{REFERENSI}

A.K. Pringgodigdo. (1980). Sejarah Pergerakan Indonesia. Jakarta: Dian Rakyat.

Kartodirdjo, S. (1972). Kolonialisme dan Nasionalisme di Indonesia abad XIXXX. Jurnal Lembaran Sejarah, (4).

Nagazumi, A. (1989). Bangkitnya Nasionalisme, Budi Utomo 1908-1918. Jakarta: Graffiti Press.

Niel, R. van. (1984). Munculnya Elite Modern Indonesia. Jakarta: Pustaka Jaya.

Poeponegoro, M. D., \& Notosusanto, N. (1984). Sejarah Nasional Indonesia (Vol. V). Jakarta: Departemen Pendidikan dan Kebudyaan.

Scherer, S. P. (1985). Keselarasan dan Kejanggalan Pemikiran-pemikiran Priyayi Nasionalis Jawa Awal Abad XX. Jakarta: Sinar Harapan.

Tirtoprodjo, S. (1986). Sejarah Kebangkitan Nasinal Indonesia. Jakarta: PT Pembangunan.

\section{Arsip dan Manuskrip}

Rijksblad Mangkunegaran Tahun 1917 No. 20; Rijksblad Mangkunegaran Tahun 1924; Solosche van Deventerschool, Koleksi Reksa Pustaka Mangkunegaran No. MN 791; Eerste verslag dari Mangkunegaransche Studiefonds (Mangkunegaran, No. Kode A. 644); Berkas-berkas permohonan studiefonds (Mangkunegaran No. Kode A. 676); Berkas tentang pembangunan HIS di Surakarta (Khazanah Badan Arsip Dan Perpustakaan Prov. Jateng: Daftar Arsip Tweede Water Staat te Semarang); Jaarverslag Tahun 1917-1944; Berkas tentang data anak sekolah masa MN VI dan MN VII; Berkas tentang data sekolahan masa MN VI dan MN VII; Berkas tentang Padvinders; Berkas tentang Kridha Mudha Mangkunegaran; Berkas tentang SRV.

\section{Referensi Lanjutan}

Darmawan, B. H. M. (1990). Mengenang BRM Soerjo Soeparto; Bergerak dan Melangkah Maju untuk Bangsanya. Surakarta: Reksa Pustaka. 
Het Studiefonds van het Mangkoenagaranshe Rijks. (1924). Majalah Jawa, (14).

Kartodirdjo, S. (1972). Kolonialisme dan Nasionalisme di Indonesia abad XIXXX. Jurnal Lembaran Sejarah, (4).

Ketika Nasib Bangsa Diperbincangkan di Sekolah Dokter Jawa. (1988). Majalah Tempo, (14).

Larson, G. D. (1990). Masa Menjelang Revolusi Kraton dan Kehidupan Politik di Surakarta, 1912-1942. Yogyakarta: Gadjah Mada University Press.

Nagazumi, A. (1983). Lahir Serta Tumbuhnya Praja Mangkunegaran. Surakarta: Reksa Pustaka.

Puspitosari, R. (1990). Studiefonds Praja Mangkunegaran Periode 1912-1945: Suatu Kajian Sejarah Ekonomi. Universitas Sebelas Maret.

Sjamsuddin, H. (1993). Sejarah Pendidikan di Indonesia Zaman Kemerdekaan, 1945-1966. Jakarta: Dep. P dan K Direktorat Jenderal Kebudayaan, Direktorat Sejarah \& Nilai Tradisional, Proyek Inventarisasi \& Dokumentasi Sejarah Nasional.

Surjomiharjo, A. (1979). Pembinaan Bangsa dan Masalah Historiografi. Jakarta: Yayasan Idayu.

Wasino. (2008). Kapitalisme Bumi Putra Perubahan Masyarakat Mangkunegaran. Yogyakarta: LKiS Pelangi Aksara. 